\title{
Two new species of Acanthobothrium (Tetraphyllidea: Onchobothriidae) from Pastinachus ef. sephen (Myliobatiformes: Dasyatidae) from the Persian Gulf and Gulf of Oman
}

\author{
Loghman Maleki ${ }^{1,2}$, Masoumeh Malek ${ }^{1}$ and Harry W. Palm ${ }^{3}$
}

\begin{abstract}
${ }^{1}$ School of Biology and Center of Excellence in Phylogeny of Living Organisms, College of Science, University of Tehran, Iran; ${ }^{2}$ Department of Biological Sciences and Biotechnology, Faculty of Science, University of Kurdistan, Sanandaj, Iran;

${ }^{3}$ Aquaculture and Sea-Ranching, Faculty of Agricultural and Environmental Sciences, University of Rostock, Rostock, Germany
\end{abstract}

\begin{abstract}
Two new species of Acanthobothrium van Beneden, 1850 from the spiral intestine of Pastinachus cf. sephen Forsskål from the Iranian coast of the Persian Gulf and the Gulf of Oman are described. To analyse the surface ultrastructure the worms were studied using light and scanning electron microscopy. Acanthobothrium jalalii $\mathrm{sp}$. $\mathrm{n}$. belongs to the category 1 species of the genus so far including 43 species. This tiny new species differs from the other category 1 species by its small total length $(2.18 \pm 0.49 \mathrm{~mm})$, number of proglottids $(4.7 \pm 0.9)$ and testes $(24 \pm 3)$, terminal segments in an apolytic condition and the shape of the cirrus-sac. Acanthobothrium sphaera sp. $\mathrm{n}$. is a small worm that belongs to the category 2 species of the genus so far including 36 species. A. sphaera sp. n. differs from the other category 2 species by its small total length (1.6 $\pm 0.2 \mathrm{~mm})$, number of proglottids $(9.6 \pm 1.2)$ and testes $(12 \pm 1)$, the presence of a vaginal sphincter and the shape of the ovary. This is the first report of Acanthobothrium from the cowtail stingray, P. cf. sephen, from the Persian Gulf and Gulf of Oman. Pastinachus sephen sensu lato has been reported as a common host of species of Acanthobothrium. Most recently, the host genus Pastinachus Rüppell has been split into five nominal species and several Acanthobothrium species infect the newly described congeners but not P. sephen. The real identity of the host studied within the present study is still in question, since sequence data of three specimens from the Gulf of Oman do not correspond to $P$. sephen sensu stricto.
\end{abstract}

Keywords: Cestoda, rays, taxonomy, surface ultrastructure, Iran, Oman

Acanthobothrium van Beneden, 1850 is the most diverse and widespread genus in the order Tetraphyllidea. Since the first record of Acanthobothrium in 1850, many species have been described mainly from tropical and subtropical elasmobranchs, especially within the last two decades (e.g. Marques et al. 1997, Campbell and Beveridge 2002, Reyda and Caira 2006, Fyler et al. 2009).

The two extensive reviews by Campbell and Beveridge (2002) from Australian waters and global survey by Fyler (2009) increased the number of Acanthobothrium species to 162. Tazerouti et al. (2009), Fyler and Caira (2010), Pramanik and Manna (2010), VardoZalik and Campbell (2011) and Zschoche et al. (2011) added another 14 to previously described species. To date, approximately 176 species can be considered valid.

Having triloculate bothridia and a pair of bipronged hooks, recognition of the genus is relatively simple compared with other tetraphyllidean cestodes. However, the species richness and cosmopolitan distribution of Acanthobothrium make identification difficult. Ghoshroy and Caira (2001) introduced four different categories for spe- cies identification within this specious taxon, based on the characters such as worm length, proglottid number, testis number and ovarian symmetry.

Common hosts for Acanthobothrium are species of the genus Pastinachus Ruppell that occur across the IndoPacific region. In the last decade, three new species have been described, resulting in five valid species of this host genus, Pastinachus sephen (Forsskål), P. atrus (Macleay), P. solocirostris Last, Manjaji et Yearsley, P. gracilicaudus Last et Manjaji-Matsumoto and P. stellurostris Last, Fahmi et Naylor (see Last et al. 2010). Only P. sephen and $P$. atrus are considered to have a wider distribution in the Indian Ocean and may also occur in the western Indian Ocean (Last et al. 2010). The other three species are restricted to the Indo-Malayan Archipelago. Using molecular diagnostics, additional species may be discovered in the western part of the Indian Ocean, including the Persian Gulf, Gulf of Oman, Arabian Sea and Red Sea (Last and Stevens 2009).

In the Persian Gulf, Haseli et al. (2010) reported at least eight species of trypanorhynchs in Pastinachus cf. sephen. 
It seems that $P$. cf. sephen is host to a species-rich cestode fauna (species of the Diphyllidea, Lecanicephalidea and Rhinebothriidea) in the Persian Gulf and Gulf of Oman. The purpose of the present study is an investigation of the Acanthobothrium diversity in $P$. cf. sephen from this region. Two new species of Acanthobothrium are described from stingrays from the Persian Gulf, including one of the category 1 species from the Gulf of Oman and one of the category 2 species from the Persian Gulf.

\section{MATERIALS AND METHODS}

A total of 47 specimens of Pastinachus cf. sephen were collected by bottom trawl net in August 2010 from Chabahar coasts $\left(25^{\circ} 11^{\prime} \mathrm{N}, 60^{\circ} 33^{\prime} \mathrm{E}-25^{\circ} 25^{\prime} \mathrm{N}, 57^{\circ} 43^{\prime} \mathrm{E}\right)$ and Bandar Abbas $\left(26^{\circ} 15^{\prime} \mathrm{N}, 53^{\circ} 02^{\prime} \mathrm{E}-27^{\circ} 04^{\prime} \mathrm{N}, 57^{\circ} 01^{\prime} \mathrm{E}\right)$, the Iranian coast of the Gulf of Oman and the Persian Gulf. They consisted of 27 males, total length $(60-129 \mathrm{~cm})$, disc width $(18-57 \mathrm{~cm})$, and $20 \mathrm{fe}-$ males, total length $(59-162 \mathrm{~cm})$, disk width $(24-59 \mathrm{~cm})$. The spiral intestines were removed and fixed in $10 \%$ formalin buffered with seawater. After one week, the samples were studied for tetraphyllidean cestodes, and the worms were removed and transferred to $70 \%$ ethanol for storage and subsequent study.

Morphological characters were studied from whole mounts and scanning electron microscopy. Worms for light microscopy were hydrated in a graded ethanol series, stained in Delafield's hematoxylin, dehydrated in a graded ethanol series, cleared in methyl salicylate and mounted onto glass slides in Canada balsam. Three scolices were prepared for SEM, with their strobila processed as morphological vouchers. Specimens were dehydrated in a graded ethanol series, transferred to $100 \%$ acetone, dried in a Critical Point Dryer BALTIC SCD004 and mounted onto carbon tape on aluminum stubs. The specimens were coated with $15 \mathrm{~nm}$ gold and studied under a SEM Zeiss DSM960A.

Illustrations were made with the help of a drawing tube. Measurements were taken with the help of an Olympus digital camera and Cellsens Dimension software attached to an Olympus BX53 light microscope. Measurements are given in micrometres except the total worm length, which is given in millimetres. The range is given, followed by the mean, standard deviation, number of measured worms and number of measurements taken in parentheses.

To facilitate comparison of the new Acanthobothrium species, the category system by Ghoshroy and Caira (2001) was used. The characters of each category, based on the available information, are given in the Global Cestode Database, (www.tapewormdb.uconn.edu). Hooks were measured with the dimensions defined by Euzet (1959), modified by Ghoshroy and Caira (2001), and include two additional measurements following Campbell and Beveridge (2002). Hook terminology for medial and lateral hooks follows Ghoshroy and Caira (2001) as follows: base length (A, A'), axial prong length (B, B'), abaxial prong length $\left(\mathrm{C}, \mathrm{C}^{\prime}\right)$ and total hook length or axial total prong length (D, D'), and the two additional measurements according to Campbell and Beveridge (2002): abaxial total prong length (E, E') and the interprong distance between the tips of the axial and abaxial prongs (W, W'). Microthrix terminology follows Chervy (2009). Museum abbreviations are: ZMB, the Natural History Museum Berlin, Germany, ZUTC, Collection of the Zoological Museum, University of Tehran,
Tehran, Iran and IPCAS, the Institute of Parasitology, České Budějovice, Czech Republic.

\section{RESULTS}

Acanthobothrium jalalii sp. $\mathrm{n}$.

Figs. 1-5, 10-15

Description (based on eight whole mounts of mature specimens, SEM of one scolex and whole mount of its voucher). Worms 1.66-3.06 mm (2.18 $\pm 0.49 ; 8$; 8) long, greatest width at level of gravid proglottid; $3-6$ (4.7 \pm 0.9 ; 8; 9) proglottids per worm; apolytic.

Scolex consisting of scolex proper and elongate cephalic peduncle. Scolex proper with four bothridia, 156-220 (177 $\pm 21 ; 8)$ long. Bothridia free posteriorly, $205-258(233 \pm 25 ; 8 ; 10)$ long by $71-111(92 \pm 12 ; 8$; 11) wide; each with three loculi and with specialized anterior region in form of triangular muscular pad; muscular pad 36-69 $(54 \pm 10 ; 8 ; 10)$ long by $55-99(85 \pm 15 ; 8 ; 10)$ wide, consisting of apical sucker and one pair of hooks at posterior margin; apical sucker 15-25 $(20 \pm 3 ; 8)$ long by $19-37(27 \pm 5.5 ; 8 ; 10)$ wide; anterior loculus $110-139$ (120 $\pm 9 ; 8 ; 13)$ long; middle loculus $27-39(32 \pm 3 ; 8 ; 12)$ long; posterior loculus $23-35(27 \pm 3 ; 8$; 13) long; ratio of locular length (anterior: middle: posterior) $1: 0.20-0.33$ $(0.31 \pm 0.1 ; 8 ; 13): 0.20-0.27(0.23 \pm 0.01 ; 8 ; 13)$; maximum width of scolex $138-208(185 \pm 22 ; 8)$ at level of anterior loculus,. Velum between adjacent bothridia absent

Hooks bipronged, hollow, each with tubercle on proximal surface of axial prong; internal channels of axial and abaxial prongs continuous; axial prongs of lateral and medial hooks longer than abaxial prongs; lateral and medial hooks approximately equal in size, axial prong of medial hook slightly longer than axial prong of lateral hook. Lateral hook measurements: A - 27-47 (38 $\pm 6 ; 8 ; 14)$, B - 39-87 (68 $\pm 13 ; 8 ; 14), C-43-79(65 \pm 11 ; 8 ; 14)$, $\mathrm{D}-63-127(101 \pm 19 ; 8 ; 14), \mathrm{E}-61-124(102 \pm 19 ; 8$; 14), W - 30-69 (41 $\pm 10,8 ; 14)$. Medial hook measurements: $A^{\prime}-25-43(35 \pm 6 ; 8 ; 14), B^{\prime}-56-103(80 \pm 13$; $8 ; 14), C^{\prime}-41-84$ (63 $\left.\pm 14,8 ; 14\right)$, D' -74138 (110 \pm 18 , 8; 14), E' - 62-124 (97 $\pm 19 ; 8 ; 14), W^{\prime}-28-64$ (43 \pm 10 ; $8 ; 14)$. Bases of lateral and medial hooks approximately equal in size, embedded in muscular pad; base of lateral and medial hooks slightly overlap. Cephalic peduncle $266-416(318 \pm 49 ; 8)$ long by $50-97(81 \pm 17 ; 8)$ wide at mid-point.

Muscular pad surface (Fig. 12) and distal bothridial surfaces (Fig. 14) covered with papilliform filitriches. Proximal bothridial surfaces covered with gladiate spinitriches (Fig. 13). Cephalic peduncle covered with densely arranged gladiate spinitriches (Fig. 15).

Proglottids acraspedote, protandrous. Immature proglottids $1-3(2.2 \pm 0.7 ; 8)$ in number. Mature proglottids $1-2(1.2 \pm 0.4,9)$ in number, $284-730(475 \pm 156 ; 9)$ long by $107-213(172 \pm 29.5$; 9) wide; mature proglottid length: width ratio $1.6-4: 1(2.7 \pm 0.82 ; 9)$. Gravid proglottid one in number, 656-2306 (1033 \pm 511 ; 9) 


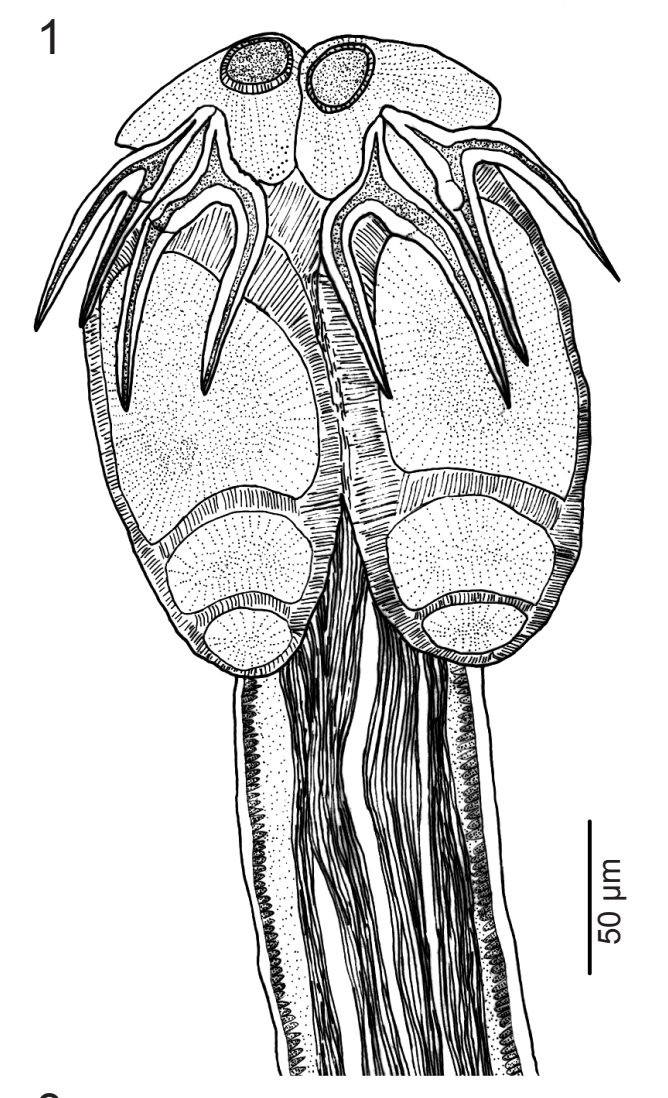

3

4
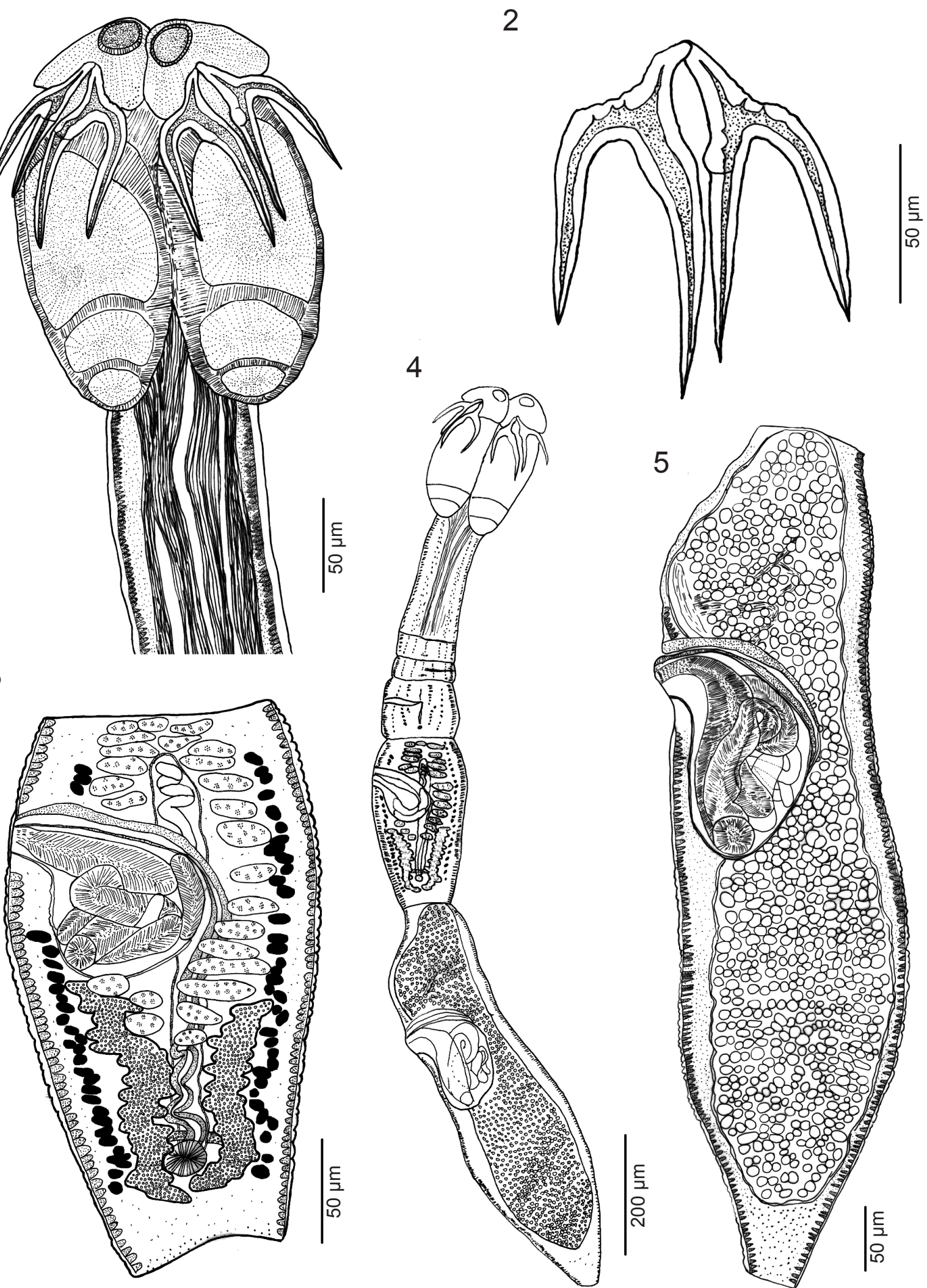

Figs. 1-5. Acanthobothrium jalalii sp. n. Fig. 1. Scolex. Fig. 2. Hooks; the hook shown on the left is medial and the hook on the right is lateral. Fig. 3. Middle mature segment. Fig. 4. Whole worm. Fig. 5. Terminal gravid segment. 
long by $144-352(217 \pm 61 ; 9)$ wide; length: width ratio $2.7-6.5: 1(4.7 \pm 1.4 ; 9)$. Genital pores marginal, irregularly alternating, $72-80 \%(76 \% \pm 3 ; 10)$ of proglottid length from posterior end.

Testes oval in frontal view, 9-24 (15 $\pm 4 ; 9 ; 20)$ long by $17-37(28 \pm 5 ; 9 ; 20)$ wide, arranged in two regular columns anterior to ovarian isthmus, 22-30 (24 \pm 3 ; 9; $10)$ in total number, $6-12(4.1 \pm 0.7 ; 9 ; 11)$ post-vaginal testes, no testes posterior to ovarian isthmus. Cirrus-sac pyriform; curved posteriorly, extending beyond midproglottid, $84-183(147 \pm 30 ; 9 ; 13)$ long by $45-120$ ( $89 \pm 20 ; 9 ; 13)$ wide, containing coiled, massive and long cirrus; cirrus expanded at base; most of length covered with spinitriches.

Ovary located at posterior half of proglottid, symmetrical, 123-287 (208 $\pm 62 ; 9 ; 8)$ long, maximum width of ovary $85-142(108 \pm 18 ; 9 ; 8)$, H-shaped in frontal view, lobulated to follicular, reaching posterior margin of cirrus-sac. Mehlis' gland posterior to ovarian isthmus. Vagina thick walled, extending from ootype along medial line of proglottid to anterior border of cirrus-sac, then laterally along anterior border of cirrus-sac to common genital atrium; vaginal sphincter absent; seminal receptacle not seen. Vitellarium follicular, follicles arranged in two lateral bands; each band consisting of two columns of oval follicles, extending from near anterior margin of testes to near posterior margin of proglottid; interrupted by genital pore and cirrus-sac, not interrupted by ovary; follicles $5-17(10.5 \pm 3 ; 9 ; 16)$ long by $8-22(14 \pm 3$; 9 ; 16) wide. Uterus median, thin-walled, sacciform, extended from ootype to near anterior part of proglottid. Eggs round in frontal view. Excretory ducts lateral.

Type host: Pastinachus $\mathrm{cf}$. sephen (Myliobatiformes: Dasyatidae).

Type 1 ocality: Gulf of Oman $\left(25^{\circ} 11^{\prime} \mathrm{N} ; 60^{\circ} 33^{\prime} \mathrm{E}-25^{\circ} 25^{\prime} \mathrm{N}\right.$; $\left.57^{\circ} 43^{\prime} \mathrm{E}\right)$, Iran.

Site of infection: Spiral intestine.

Type material: Holotype (ZUTC Platy. 1291), four paratypes (ZUTC Platy. 1292-ZUTC Platy. 1295), one SEM voucher (ZUTC Platy. 1296), one paratype (IPCAS C - 639), two paratypes (ZMB E.7559).

Et y mology: This species is named after the late Dr. Behiar Jalali Jafari, Islamic Azad University, Tehran Science and Research Branch, for his contribution to the knowledge of fish parasites from Iran.

Remarks. Acanthobothrium jalalii sp. n. is a category 1 species based on Ghoshroy and Caira (2001), i.e. $\leq 15 \mathrm{~mm}$ total length, $\leq 50$ proglottids, $\leq 80$ testes and symmetrical ovary. To date 43 category 1 species have been identified. Acanthobothrium jalalii differs from all other category 1 species except Acanthobothrium nanogravidum Zschoche, Caira et Fyler, 2011 from Pastinachus atrus. Both $A$. jalalii and $A$. nanogravidum are apolytic, i.e. both have gravid proglottids on the strobilae and both occur in the Indo-Pacific region. A. jalalii differs from $A$. nanogravidum in cirrus-sac length $(137-183 \mu \mathrm{m}$ vs $63-96 \mu \mathrm{m})$ and in position of the genital pore from the posterior end (72-80\% A. jalalii vs 42-57\% A. nanogravidum).

Among the other category 1 species, A. jalalii is a shorter worm $(1.7-3.1 \mathrm{~mm})$ than $A$. semnovesiculum Verma, 1928 (3.5-7.0 mm), A. romanowi Fyler, Caira et Jensen, 2009 (4.0-7.1 mm), A. chisholmae Campbell et Beveridge, 2002 (4.3-4.4 mm), A. southwelli Subhapradha, 1955 (5 mm), A. paulum Linton, 1890 (6-19 mm), A. gasseri Campbell et Beveridge, 2002 (6.5-12.2 cm), A. cartagenesis Brooks et Mayes, $1980(25 \mathrm{~mm})$ and A. manteri Hassan, 1983 (36-65 mm), and a longer worm than A. gnomus Reyda et Caira, 2006 (0.8-1.4 mm).

It possesses fewer proglottids (3-6) than $A$. asnihae Fyler et Caira, 2006 (8-12), A. hypermekkolpos Fyler et Caira, 2010 (8-10), A. martini Campbell et Beveridge, 2002 (9-13), A. schalli VardoZalik et Campbell, 2011 (10-23), A. bartonae Campbell et Beveridge, 2002 (11), A. foulki Reyda et Caira, 2006 (11-17), A. saliki Fyler et Caira, 2006 (11-19), A. fogeli Goldstein, 1964 (12-32), A. nicoyaense Brooks et McCorquodale, 1995 (13-19), A. clarkeae Campbell et Beveridge, 2002 (14-21), A. zainali Fyler et Caira, 2006 (15-21), A. himanturi Brooks, 1977 (17-26), A. marplatense Ivanov et Campbell, 1998 (18-30), A. royi Caira et Burge, 2001 (19-26), A. walkeri Campbell et Beveridge, 2002 (21-36) A. urolophi Schmidt, 1973 (22-28), A. laurenbrownae Campbell et Beveridge, 2002 (23-37), A. monksi Marques, Brooks et Barriga, 1997 (24-48), A. dollyae Caira et Burge, 2001 (33-48) and A. peruviense Reyda, 2008 (34-57).

The new species possesses a longer cephalic peduncle than A. ulmeri VardoZalik et Campbell, 2011 and $A$. lepidium Reyda et Caira, 2006 (266-416 $\mu \mathrm{m}$ vs 48-176 and 75-200 $\mu \mathrm{m}$, respectively). The new species has more testes per proglottid than $A$. minusculum Marques, Brooks et Barriga, 1997, A. oceanharvestae Fyler, Caira et Jensen, 2009, A. zimmeri Fyler, Caira et Jensen, 2009 (22-30 vs 6-10, 10-14 and 10-19, respectively), and fewer testes than A. lintoni Goldstein, Henson et Schlicht, 1968, A. odonoghuei Campbell et Beveridge, 2002, A. atahualpai Marques, Brooks et Barriga, 1997, A. guptai Shinde et Bhagwan, 2002, and A. pearsoni Williams, 1962 (22-30 vs 30-46, 31-34, 35-61, 44-45 and 50-56, respectively). Acanthobothrium jalalii differs from $A$. lineatum Campbell, 1969, A. mathiasi Euzet, 1959 and A. rohdei Campbell et Beveridge, 2002 in that it lacks a vaginal sphincter. The new species differs from $A$. larsoni Reyda et Caira, 2006 and A. marymichaelorum Towhig, Caira et Fyler, 2008 in the lack of postovarian testes. The position of the genital pore in $A$. jalalii differs from that of $A$. west $i$ VardoZalik et Campbell, 2011, A. jeanneae Fyler et Caira, 2010 and A. lentiginosum VardoZalik et Campbell, 2011 (72-80\% vs 45-56, 52-68 and 59-69\%, respectively). 
Acanthobothrium sphaera sp. n.

Figs. 6-9, 16-20

Description (based on 14 whole mounts of mature specimens, SEM of two scolices and whole mounts of their vouchers). Worms $1.25-2.02 \mathrm{~mm}(1.6 \pm 0.2 ; 14 ; 13)$ long; greatest width at level of scolex; $8-13(9.6 \pm 1.2 ; 14$; 13) proglottids per worm; euapolytic.

Scolex consisting of scolex proper and conspicuous cephalic peduncle. Scolex proper with four bothridia, 141-195 (161 $\pm 17 ; 14 ; 9)$ long. Bothridia free posteriorly, $220-295$ (245 $\pm 24 ; 14 ; 9)$ long by $80-112$ (96 $\pm 10 ; 14$; 9 ) wide; each with three loculi and specialized anterior region in form of triangular muscular pad; muscular pad $54-68(63 \pm 5 ; 14 ; 6)$ long by $69-91(82 \pm 8 ; 14 ; 6)$ wide, with apical sucker and one pair of hooks at posterior margin, apical sucker $17-27(21 \pm 4.6 ; 14 ; 6)$ long by $25-41$ $(36 \pm 6.3 ; 14 ; 6)$ wide; anterior loculus $129-156$ (139 \pm 9 ; 14 ; 10) long; middle loculus $19-36(30 \pm 5 ; 14 ; 10)$ long; posterior loculus $19-26(22 \pm 2 ; 14 ; 10)$ long; ratio of loculus length (anterior: middle: posterior) $1: 0.14-0.23$ $(0.19 \pm 0.10): 0.14-0.2(0.15 \pm 0.20)$; maximum width of scolex at level of anterior loculus; scolex width 183-217 $(199 \pm 10.8 ; 10)$. Velum between adjacent bothridia absent.

Hooks bipronged, hollow, with tubercle on proximal surface of axial prong; internal channels of axial and abaxial prongs continuous, axial prongs of lateral and medial hooks slightly longer than abaxial prongs; lateral and medial hooks approximately equal in size; axial prong of medial hook slightly longer than axial prong of lateral hook. Lateral hook measurements: A - 36-44 (40 \pm 2 ; 14; 20), B - 67- 97 (76 $\pm 7 ; 14 ; 20), \mathrm{C}-62-78(69 \pm 4 ; 14$; 20), D - 102-119 (109 $\pm 5 ; 14 ; 20) \mathrm{E}-99-122(108 \pm 6$; $14 ; 20) \mathrm{W}-33-56(43 \pm 6 ; 14 ; 20)$. Medial hook measurements: A'-33-41 (38 $\pm 2 ; 14 ; 20), B^{\prime}-69-94$ (81 $\pm 7 ; 14$; 20), C' - 66-84 (71 $\pm 4.7 ; 14 ; 20)$, D' - 102-127 (112 \pm 6 ; $14 ; 20)$ E' $-97-120(108 \pm 5 ; 14 ; 20) W^{\prime}-30-56$ (45 \pm 7 ; $14 ; 20)$. Bases of lateral and medial hooks approximately equal in size; embedded in muscular pad; bases of lateral and medial hooks do not overlap each other. Cephalic peduncle $148-245(183 \pm 29 ; 14 ; 11)$ long by $87-120(102 \pm$ $11 ; 14 ; 11)$ wide at mid-point.

Muscular pad surface (Fig. 18) and distal bothridial surfaces (Fig. 19) with papilliform filitriches. Proximal bothridial surfaces covered with gladiate spinitriches (Fig. 19). Papilliform filitriches interspersed with gladiate spinitriches on bothridial rims (Fig. 19). Cephalic peduncle covered with densely arranged gladiate spinitriches (Fig. 20).

Proglottids acraspedote, protandrous. Immature proglottids $6-10(7 \pm 1 ; 14 ; 13)$ in number; mature proglottids $1-4(3 \pm 1 ; 16 ; 15)$ in number. Terminal mature proglottid $319-736(482 \pm 100 ; 16 ; 15)$ long by $121-190$ $(155 \pm 17 ; 16 ; 15)$ wide, length: width ratio $2.0-4.5: 1$ $(3.1 \pm 0.7 ; 16 ; 15)$. Genital pores marginal, irregularly al- ternating, $59-72 \%(64 \% \pm 3 ; 16 ; 15)$ of proglottid length from posterior end; gravid proglottids not observed.

Testes round in frontal view, 24-42 $(30 \pm 6 ; 16 ; 22)$ long by $23-39(30 \pm 5 ; 16 ; 22)$ wide, arranged in two regular columns anterior to ovarian isthmus, 10-14 (12 \pm 1 ; $14 ; 13)$ in total number, $3-4(3 \pm 1 ; 14 ; 13)$ post-vaginal testes, no testes posterior to ovarian isthmus. Cirrus-sac round to relatively oval, extending beyond mid-proglottid, $71-112(89 \pm 13 ; 16 ; 13)$ long by $48-82(68 \pm 11.5 ; 16$; 13) wide, containing coiled cirrus, expanded at base; base and distal length covered with spinitriches.

Ovary located at posterior half of proglottid, asymmetrical; poral lobe $135-259(182 \pm 41 ; 16 ; 12)$ long; aporal lobe $133-260(196 \pm 46 ; 16 ; 12)$, maximum width 57-90 $(79 \pm 10 ; 16 ; 12), \mathrm{H}$-shaped in frontal view, lobulated to follicular; reaching posterior margin of cirrus-sac; Mehlis' gland posterior to ovarian isthmus. Vagina thick-walled, extending from ootype along medial line of proglottid to anterior border of cirrus-sac, then laterally following anterior border of cirrus-sac to common genital atrium; vaginal sphincter present; seminal receptacle not seen. Vitellarium follicular, consisting of two lateral bands; each band consisting of two columns of relatively large and oval follicles, extending from near anterior margin of testes to near posterior margin of proglottid; interrupted by genital pore and cirrus-sac; follicles $11-26(20 \pm 4 ; 16$; $20)$ long by $12-27(20 \pm 4 ; 16 ; 20)$ wide. Uterus median, thick walled, sacciform, extending from near anterior margin of proglottid to near posterior margin of proglottid. Excretory ducts lateral, in a ventral and dorsal pair. Eggs not observed. Excretory ducts lateral.

Type host: Pastinachus cf. sephen (Myliobatiformes: Dasyatidae).

Type locality: Persian Gulf $\left(26^{\circ} 15^{\prime} \mathrm{N}, 53^{\circ} 02^{\prime} \mathrm{E}-27^{\circ} 04^{\prime} \mathrm{N}\right.$, $\left.57^{\circ} 01^{\prime} \mathrm{E}\right)$, Iran.

Site of infection: Spiral intestine.

Type material: Holotype (ZUTC Platy. 1298), nine paratypes (ZUTC Platy. 1299-ZUTC Platy. 1307), two SEM vouchers (ZUTC Platy. 1308-ZUTC Platy. 1309), one paratype (IPCAS C - 641) three paratypes (ZMB E7560).

Ety mology: This species is named because of an approximately round shape of the ovarian follicles and testes in frontal view.

Remarks. Acanthobothrium sphaera sp. n. is a category 2 species based on Ghoshroy and Caira (2001), i.e. $\leq 15 \mathrm{~mm}$ total length, $\leq 50$ proglottids, $\leq 80$ testes and asymmetrical ovary. To date, 36 category 2 species have been recognized. In addition to these species, comparison has been done with Acanthobothrium species parasitizing Pastinachus. Acanthobothrium sphaera is smaller (1.25-2.02 mm) than A. ocallaghani Campbell et Beveridge, 2002 (2.5-3.2 mm), A. bobconniorum Fyler et Caira, 2010 (3-5 mm), A. annapinkiensis Carvajal et Goldstein, 1971 (2.5-3.2 mm), A. semnovesiculum 

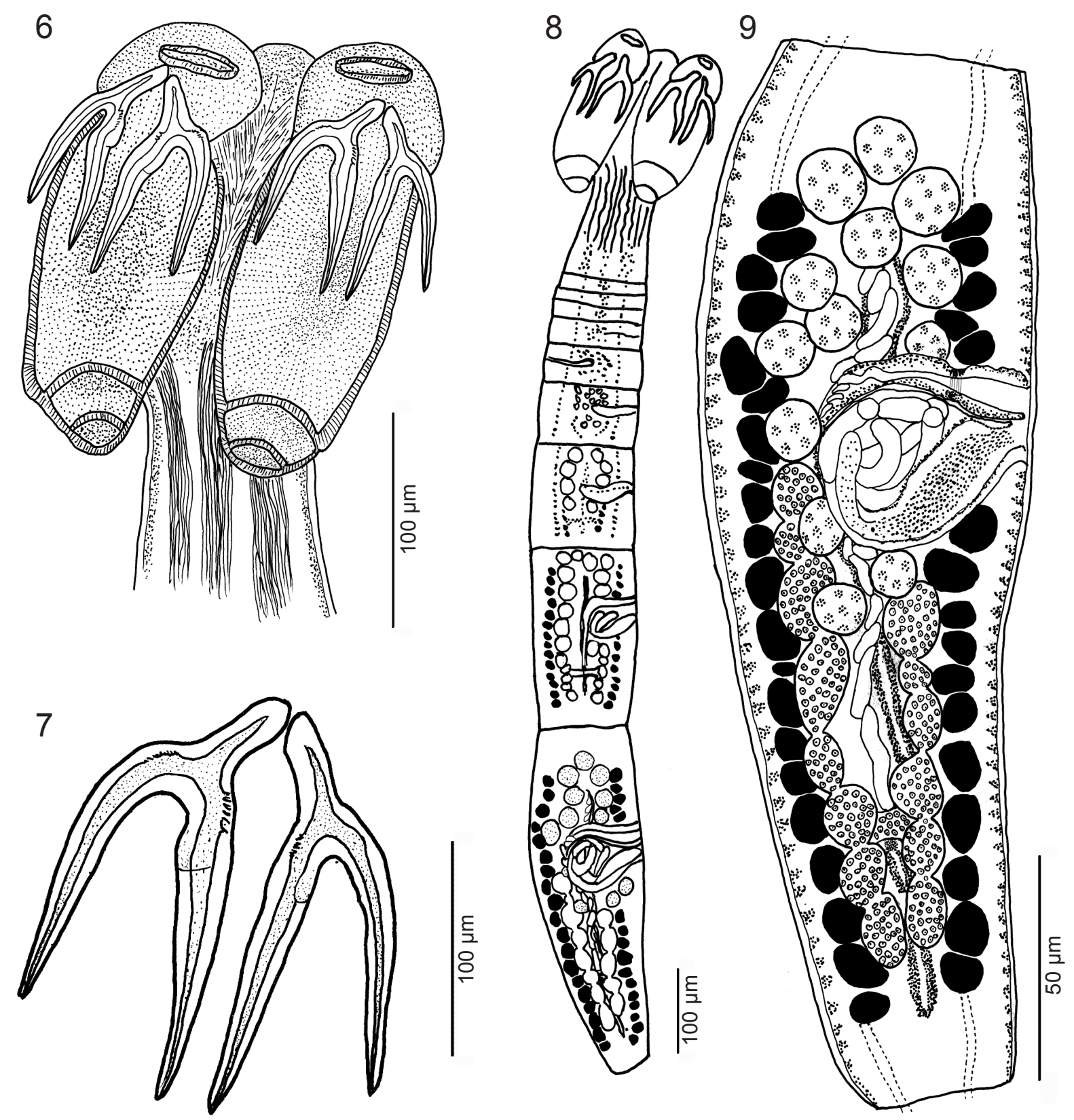

Figs. 6-9. Acanthobothrium sphaera sp. n. Fig. 6. Scolex. Fig. 7. Hooks; the hook shown on the left is medial, the hook on the right is lateral. Fig. 8. Whole worm. Fig. 9. Terminal mature segment.

Verma, 1928 (3.5-7.0 mm), A. manteri Hassan, 1983 (36-65 mm) and A. gasseri Campbell et Beveridge, 2002 $(6.5-12.2 \mathrm{~cm})$.

Acanthobothrium sphaera has fewer proglottids than A. walkeri Campbell et Beveridge, 2002, A. laurenbrownae Campbell et Beveridge, 2002, A. masnihae Fyler et Caira, 2006 and A. tetabuanense Reyda et Caira, 2006 (8-13 vs 21-36, 23-37, 23-43, 25-36, respectively) and more proglottids than A. tripartitum Williams, 1969, A. lasti Campbell et Beveridge, 2002, and A. mooreae Campbell et Beveridge, 2002 (8-13 vs 3, 5-7, 5-7, respectively). Acanthobothrium sphaera is a euapolytic worm whereas A. nanogravidum is an apolytic worm. It has a smaller posterior loculus than $A$. rajivi Ghoshroy et

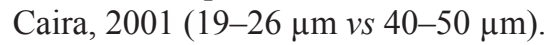

Acanthobothrium sphaera possesses fewer testes (10-14) compared with the following species: A. campbelli Marques, Brooks et Monks, 1995 (15-23), A. minus Tazerouti, Kechemir-Issad et Euzet, 2009 (17-25), A. quadripartitum Williams, 1968 (18), A. tasajerasi Brooks, 1977 (19-33), A. dujardini van Beneden, 1850 (20-30), A. vargasi Marques, Brooks et Monks, 1995 (22-29), A. coquimbensis Carvajal et Jeges, 1980 (22-40), A. edwardsi Williams, 1969 (23-26), A. chisholmae 

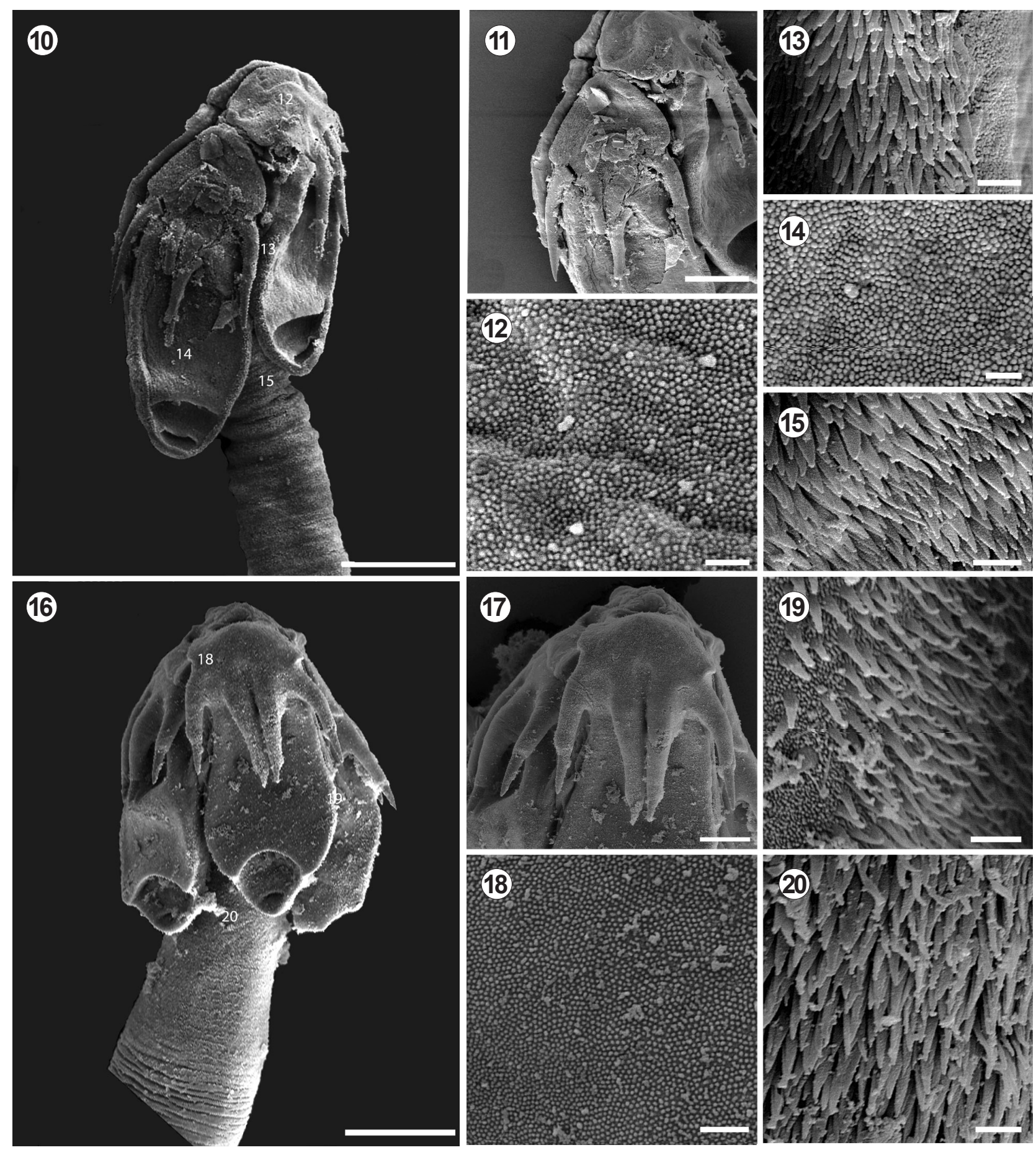

Figs. 10-15. Scanning electron micrographs of Acanthobothrium jalalii sp. n. Fig. 10. Scolex. Note: small numbers on scolex correspond to the figures showing higher magnification images of these surfaces. Fig. 11. Apical pad and hooks. Fig. 12. Surface of apical pad. Fig. 13. Proximal bothridial surface. Fig. 14. Distal bothridial surface. Fig. 15. Cephalic peduncle surface. Figs. 16-20. Scanning electron micrographs of Acanthobothrium sphaera sp. n. Fig. 16. Scolex. Fig. 17. Apical pad and hooks. Fig. 18. Surface of apical pad. Fig. 19. Proximal and distal bothridial surface. Left side is proximal and right side is distal. Fig. 20. Cephalic peduncle surface. Scale bars: Figs. 10, $16=80 \mu \mathrm{m}$; Fig. $11=40 \mu \mathrm{m}$; Figs. 12, $14=1 \mu \mathrm{m}$; Figs. $13,15,18-20=2 \mu \mathrm{m}$; Fig. $17=30 \mu \mathrm{m}$.

(23-27), A. urotrygoni Brooks et Mayes, 1980 (24-33), A. dasi Ghoshroy et Caira, 2001 (24-41), A. olseni Dairley et Mudry, 1968 (26-39), A. zapterycum Ostrowski de Núñez, 1971 (30-35), A. bullardi Ghoshroy et Caira,
2001 (30-47), A. bray Campbell et Beveridge, 2002 (30-68), A. gloveri Campbell et Beveridge, 2002 (32-42), A. brachyacanthum Riser, 1955 (33-34), A. popi Fyler, Caira et Jensen, 2009 (37-50), A. costarricense Marques, 
Brooks et Monks, 1995 (37-62), A. puntarenasense Marques, Brooks et Monks, 1995 (38-58), A. cimari Marques, Brooks et Monks, 1995 (42-62), A. guptai Shinde et Bhagwan, 2002 (44-45), A. lilium Baer et Euzet, 1962 (46-58) and A. woodsholei Baer, 1948 (50-55).

Acanthobothrium sphaera can be differentiated in the distance of the genital pore from the posterior end of the segment from $A$. stevensi Campbell et Beveridge, 2002 and A. thomasae Campbell et Beveridge, 2002 (59-72\% vs 37-50\% and 40-47\%, respectively). Acanthobothrium sphaera differs from $A$. jalalii, the only other congener reported from $P$. cf. sephen, in that it has a vaginal sphincter and is a euapolytic worm.

\section{DISCUSSION}

The study of the marine cestode fauna in the Persian Gulf and the Gulf of Oman is just at the beginning. El Naffar et al. (1992) and Hassan et al. (2002) reported a diversity of trypanorhynch cestodes in teleosts from the Persian Gulf and Gulf of Oman, and Haseli et al. (2010) and Haseli et al. (2011) investigated the trypanorhynch cestode diversity in teleosts and elasmobranchs from the Persian Gulf. Malek et al. (2010) reported two new species of Paraorygmatobothrium from the Persian Gulf and Caira et al. (2011) erected a new genus of the Phyllobothriidae from carcharhiniform sharks from Iran and Australia. Haseli et al. (2012) added two new species of the Diphyllidea from the Persian Gulf and the present study reports two species from the tetraphyllidean genus Acanthobothrium from Pastinachus cf. sephen from Iranian waters for the first time.

There is no previous record of Acanthobothrium species from the Persian Gulf, although several Acanthobothrium species have been reported from the surrounding waters, such as the Arabian Sea, Sri Lanka and Indian waters, especially the Bay of Bengal. With the description of $A$. herdmani Southwell, 1912, the first record of Acanthobothrium was provided by Southwell (1912) from the Bay of Bengal. Most recently, Pramanik and Manna (2010) reported three new Acanthobothrium species from the Bay of Bengal, adding to a total number of 25 species reported so far from the North-West Indian Ocean. According to the host species from the region, the genus Acanthobothrium mainly occurs in dasyatids (11 species), gymnurids (one species) myliobatids (two species) and guitarfishes (three species). It is common to find more than one Acanthobothrium species in the one single host species (Campbell and Beveridge 2002, Fyler and Caira 2006, Reyda and Caira 2006, Fyler et al. 2009), similar to the present study in which at least 2 species of Acanthobothrium were found within $P$. cf. sephen.

Until recently, $P$. sephen was considered a monotypic species and most researchers consequently identified all captured specimens of Pastinachus from the Persian Gulf and Gulf of Oman as P. sephen. According to Last et al. (2010), five valid species of Pastinachus do exist, four of them mainly from the Indo-Malay Archipelago (Zschoche et al. 2011). Since $P$. sephen is the only species of Pastinachus that has been reported throughout the West Indian Ocean, it would seem likely that the Pastinachus species in the Persian Gulf is also P. sephen. The true identity of the sampled specimens of the the present study, however, remains doubtful, and may represent an undescribed species of Pastinachus. Although Last and Stevens (2009) reported that $P$. sephen is the predominant species in the nearby Red Sea and Persian Gulf, there is DNA evidence that a different species of Pastinachus exists in the Persian Gulf. The molecular analyses by Naylor et al. (2012) of three specimens with code GN6651 from Gulf of Oman demonstrated no correspondence with the known sequence of $P$. sephen, leading to designation as $P$. cf. sephen. Data about these specimens are available in Global Cestode Database via the following link: tapewormdb.uconn.edu/index.php/ hosts/specimen_details/elasmobranch/5518. The host specimens in this study have not been studied for molecular analysis but were similar to the specimens from the Gulf of Oman examined by Naylor et al. (2012) and identified as $P$. cf. sephen. Further morphological and molecular data on elasmobranchs from the Persian Gulf are needed to clarify the identity of Pastinachus species in this region.

With the present study, ten species of Acanthobothrium have been reported from Pastinachus, including A. guptai, A. semnovesiculum (both from India), A. chisholmae, A. gasseri, A. laurenbrownae, A. walkeri (all Australia), A. manteri (Egypt), A. nanogravidum (Australia), and the two new species $A$. jalalii and $A$. sphaera (both from Iran). Prior to 2005, hosts of all Acanthobothrium species that have been reported from Pastinachus, were recorded as Pastinachus sephen.

Zschoche et al. (2011) made the following changes to host identifications of species of Acanthobothrium reported from Pastinachus species prior to their study: Pastinachus atrus likely is host for all Australian species, thus leaving Pastinachus sephen (sensu strictu) as only the type host of $A$. guptai and A. semnovesiculum, both from India. Further studies are needed within this speciose cestode genus and the molecular analyses of their hosts should be included.

Acknowledgments. We would like to thank Dr. Tooraj Valinasab from the Fisheries Research Organization of Iran for supporting the host collection, the Iranian Ministry of Science, Research and Technology, the University of Tehran, Department of Environment of Iran for their financial supports and the Electron Microscopic Centre at University of Rostock. We also would like to thank the editor and anonymous reviewers for their critical comments. This study was partially supported by the NSF Planetary Biodiversity and Inventory (PBI) collaborative grant (Award Nos. 0818696 and 0818823). 
Caira J.N., Malek M., Ruhnke T. 2011: A new genus of Phyllobothriidae (Cestoda: Tetraphyllidea) in carcharhiniform sharks from Iran and Australia. J. Helminthol. 85: 40-50.

Campbell R.A., Beveridge I. 2002: The genus Acanthobothrium (Cestoda: Tetraphyllidea: Onchobothriidae) parasitic in Australian elasmobranch fishes. Invertebr. Syst. 16: 237-344.

Chervy L. 2009: Unified terminology for cestode microtriches: a proposal from the International Workshops on Cestode Systematics in 2002-2008. Folia Parasitol. 56: 199-230.

El Naffar M.K.I., Gobashy A.F., El Etreby S.G., Kardousha M.M. 1992: General survey of helminth parasites genera of Arabian Gulf fish (coasts of United Arab Emirates). Arab Gulf J. Sci. Res. 10: 99-110.

Euzet L. 1959: Recherches sur les cestodes tétraphyllides des Sélaciens des Côtes de France. PhD Thesis, University of Montpellier, France, 263 pp.

FyLER A.C. 2009: Systematics, biogeography and character evolution in the tapeworm genus Acanthobothrium van Beneden, 1850. $\mathrm{PhD}$ thesis, University of Connecticut, Connecticut, USA, $182 \mathrm{pp}$.

Fyler C.A., CAira J.N. 2006: Five new species of Acanthobothrium (Cestoda: Tetraphyllidea) from the freshwater whipray (Himantura chaophraya). J. Parasitol. 92: 105-125.

Fyler C.A., Caira J.N. 2010: Phylogenetic status of four new species of Acanthobothrium (Cestoda: Tetraphyllidea) parasitic on the wedgefish Rhynchobatus laevis (Elasmobranchii: Rhynchobatidae): implications for interpreting host associations. Invertebr. Syst. 24: 419-433.

Fyler C.A., Caira J.N., Jensen K. 2009: Five new species of Acanthobothrium (Cestoda: Tetraphyllidea) from an unusual species of Himantura (Rajiformes: Dasyatidae) from northern Australia. Folia Parasitol. 56: 107-128.

Ghoshroy S., Caira J.N. 2001: Four new species of Acanthobothrium (Cestoda: Tetraphyllidea) from the whiptail stingray Dasyatis brevis in the Gulf of California, Mexico. J. Parasitol. 87: 354-372.

Haseli M., Malek M., Palm H.W. 2010: Trypanorhynch cestodes of elasmobranchs from the Persian Gulf. Zootaxa 2492: 28-48.

Haseli M., Malek M., Palm H.W., Ivanov V.A. 2012: Two new species of Echinobothrium van Beneden, 1849 (Cestoda: Diphyllidea) from the Persian Gulf. Syst. Parasitol. 82: 201-209.

Haseli M., Malek M., Valinasab T., Palm H.W. 2011: Trypanorhynch cestodes of teleost fish from the Persian Gulf, Iran. J. Helminthol. 85: 215-224.

Hassan M.A., Palm H.W., Mahmoud M.A., Jama F.A. 2002: Trypanorhynch cestodes from the musculature of commercial fishes from Arabian Gulf. Arab Gulf J. Sci. Res. 20: 74-86.
Last P.R., Manjaji-Matsumoto B.M. 2010: Description of a new stingray, Pastinachus gracilicaudus sp. nov. (Elasmobranchii: Myliobatiformes), based on material from the Indo-Malay Archipelago. In: P.R. Last, W. T. White and J.J. Pogonoski (Eds.), Descriptions of New Sharks and Rays from Borneo. CSIRO, Hobart, pp. 101-114.

Last P.R., Stevens J.D. 2009: Sharks and Rays of Australia. Harvard University Press, Cambridge, 644 pp.

MaleK M., Caira J.N., Haseli M. 2010: Two new species of Paraorygmatobothrium Ruhnke, 1994 (Cestoda: Tetraphyllidea) from the carcharhinid shark Carcharhinus cf. dussumieri (Müller and Henle) in the Persian Gulf. Syst. Parasitol. 76: 59-68.

Marques F., Brooks D.R., Barriga R. 1997: Six species of Acanthobothrium (Eucestoda: Tetraphyllidea) in stingrays (Chondrichthyes: Rajiformes: Myliobatoidei) from Ecuador. J. Parasitol. 83: 475-484.

Naylor G.J.P., Caira J.N., Jensen K., Rosana K.A.M., White W.T., LAST P.R. 2012: A DNA sequence-based approach to the identification of sharks and rays species and its implications for global elasmobranch diversity and parasitology. Bull. Am. Mus. Nat. Hist. 367, 262 pp.

Pramanik P.B., Manna B. 2010: On three new species and known species of the genus Acanthobothrium van Beneden, 1849 (Cestoidea: Onchobothridae) from the cartilaginous fishes from Digha waters, Bay of Bengal, India. J. Nat. Hist. 6: 24-45.

Reyda F., Caira J.N. 2006: Five new species of Acanthobothrium (Cestoda: Tetraphyllidea) from Himantura uarnacoides (Rajiformes: Dasyatidae) in Malaysian Borneo. Comp. Parasitol. 43: 49-71.

Southwell T. 1912: A description of ten new cestode parasites from marine fishes of Ceylon with notes on other cestodes from the same region. Rep. Ceylon. Mar. Biol. Lab. 22: 259-278.

Tazerouti F., Kechemir-Issad N., Euzet L. 2009: Acanthobothrium minus n. sp. (Tetraphyllidea: Onchobotriidae) parasite de Raja asterias (Elasmobranchii: Rajidae) en Méditerranée. Parasite. 16: 203-207.

VardoZalik A.M., Campbell R.A. 2011: Five new species of Acanthobothrium van Beneden, 1849 (Cestoda: Tetraphyllidea) in elasmobranchs from the northwest Atlantic and Gulf of Mexico with first records from smooth-hound sharks and guitarfish. Zootaxa. 2838: 41-64.

Zschoche M., Caira J.N., Fyler C.A. 2011: A new species of Acanthobothrium van Beneden, 1850 (Tetraphyllidea: Onchobothriidae) from Pastinachus atrus (Macleay) (Batoidea: Dasyatidae) in Australian waters, with a reassessment of the host associations of Acanthobothrium spp. parasitising Pastinachus spp. Syst. Parasitol. 78: 109-116.

Accepted 9 May 2013 